CENTRE for ECONOMIC

$P$ E R F O R M A N C E

CEP Discussion Paper No 698

July 2005

\title{
Ex Post Versus Ex Ante Measures \\ of the User Cost of Capital \\ Nicholas Oulton
}

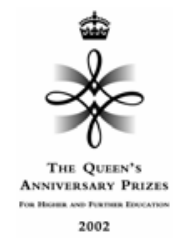




\begin{abstract}
When doing growth accounting, should we use ex post or ex ante measures of user costs to calculate the contribution of capital? The answer, based on a simple model of temporary equilibrium, is that ex post is better in theory. In practice researchers usually calculate ex post user costs by assuming that the rate of return is equalised across assets. But this is only true if expectations are correct. A numerical example shows that either ex ante or ex post can be closer to the true measure, depending on the parameters. I propose a hybrid method that makes use of elements of both approaches. I test this and the other methods using data for 31 UK industries.
\end{abstract}

Keywords: User cost, capital, ex post, ex ante, growth accounting JEL Classifications: O470, E010, C430, E220

Data: Bank of England Industry Dataset

This paper was produced as part of the Centre's Productivity and Innovation Programme. The Centre for Economic Performance is financed by the Economic and Social Research Council.

\title{
Acknowledgements
}

I am grateful to Dale Jorgenson for helpful comments. This paper benefited from discussion at the 2nd consortium meeting of the EU KLEMS group in Helsinki, June 9-11, 2005. I owe thanks to the Bank of England for permission to use the Bank of England Industry Dataset. This research was made possible by financial support under the 6th Framework Programme of the European Commission to the "EU KLEMS Project on Productivity in the European Union". The views expressed are my own.

Nicholas Oulton is a Senior Visiting Research Fellow at the Centre for Economic Performance, London School of Economics. Email: n.oulton@1se.ac.uk

Published by

Centre for Economic Performance

London School of Economics and Political Science

Houghton Street

London WC2A $2 \mathrm{AE}$

All rights reserved. No part of this publication may be reproduced, stored in a retrieval system or transmitted in any form or by any means without the prior permission in writing of the publisher nor be issued to the public or circulated in any form other than that in which it is published.

Requests for permission to reproduce any article or part of the Working Paper should be sent to the editor at the above address.

(C) Nicholas Oulton, submitted 2005

ISBN 0753018780 


\section{Introduction}

In order to do growth accounting we need to estimate the contribution of capital to the growth of output. This contribution equals the elasticity of output with respect to capital services multiplied by the growth of capital services. In the real world there are many types of capital so we need to estimate an index of the growth of capital services. For the latter we need estimates of the user cost (rental price) of each asset to employ as weights, on the assumption that user costs measure marginal products. Some of the elements of the user cost, eg asset prices, are known ex post but not with certainty ex ante. Another element, the rate of return, is still more problematic. The standard approach (eg Jorgenson and Griliches, 1967; Christensen and Jorgenson , 1969; and Jorgenson, Gollop and Fraumeni, 1987) has been to use an ex post measure; this is sometimes also called the endogenous approach. In the ex post approach it is assumed that the rate of return is equalised across assets. Then this unknown rate can be found by using the condition that the sum of the returns across assets (where the return on an asset is the product of its user cost and the flow of capital services that it yields) equals observed, total profit (gross operating surplus in national accounts language). The alternative, ex ante approach, sometimes also called the exogenous approach, employs a rate of return derived from external information, eg from financial market data, together often with estimates of expected, rather than actual, asset price inflation.

Many (eg Schreyer et al, 2003: Schreyer, 2004) have felt uncomfortable with the ex post approach. After all, investment decisions have to be made in advance of knowing all the relevant facts. Surely agents employ some notion of the required rate of return in deciding how much to invest, and this required rate may differ from the actual, realised rate? Equally, they must base their decisions on expected, not actual, capital gains and losses. Using the ex post measure would seem to imply either that all expectations are realised (a world of perfect certainty) or that the quantities of capital can be instantaneously adjusted to the desired levels, after all uncertainties have been resolved. Neither assumption seems attractive a priori. ${ }^{1}$ This suggests using an ex ante approach. On the other hand, when doing growth accounting we are interested in what the contribution of capital actually was, not in what it was expected to be, and for this the ex post approach seems preferable (Berndt and Fuss, 1986).

\footnotetext{
1 The OECD capital and productivity manuals (OECD, 2001a and b) mention the ex post and ex ante alternatives but without substantive discussion as to which is preferable.
} 
The purpose of this paper is to assess the case for and against ex post and ex ante measures. It should be obvious that the correct measure of the user cost depends on the underlying model. So in Section 2 I set out a simple model that is very similar to that of Berndt and Fuss (1986). Here firms have to choose the levels of their asset stocks before knowing the price of output and the wage with certainty. Once these data are revealed, firms can choose their labour input but cannot adjust their capital input till the next period. This model, if true, tells us how we ought to do growth accounting. According to this model, the ex post user costs are the correct measures to use. But Section 3, which considers how both methods are applied in practice, shows that the common method of calculating ex post user costs is not in general correct. The reason is that unless all expectations are realised, ex post rates of return differs between assets even though ex ante they are expected to be the same. So the growth of capital services may be better measured using the ex ante method, though this is not guaranteed to be the case in practice, since firms' expectations cannot be measured exactly. However, within the usual assumptions of growth accounting, the overall weight to be applied to the index of capital services growth when calculating TFP growth should be the ex post, not the ex ante, profit share, which is easily observed. I then go on to suggest a hybrid method of estimating the capital services index, which uses elements of both the ex ante and the ex post approaches. An advantage of this hybrid approach is that it uses exactly the same readily observable data as does the ex post approach. Section 4 illustrates these ideas with a numerical example based on a three-input CES production function. Section 5 checks how much difference method makes to the results using UK data for 31 industries covering the whole economy. Section 6 concludes.

\section{The model}

Consider an economy where investment decisions have to be made at the beginning of the period, before the price of output or the price of the asset at the end of the period are known with certainty. At the end of the period the price of output and also the level of demand is revealed. According to standard theory, the ex ante (expected) real user cost of the $i$ th type of asset $(i=1, \ldots, m)$, denoted by $q_{i t}^{e}$, is then:

$$
q_{i t}^{e}=E_{t-1}\left\{T_{i t}\left[r_{t}^{*}+\delta_{i}\left(1+\pi_{i t}\right)-\pi_{i t}\right]\left(p_{i, t-1} / p_{Y t}\right)\right\}
$$


Here $E_{t-1}$ denotes the expectation conditional on information available at the end of period $t$ $1, r_{t}^{*}$ is the required rate of return during period $t, \delta_{i}$ is the rate of depreciation, $p_{i, t-1}$ is the asset price of the $i$ th type at the beginning of the period (end of the previous period), $T_{i t}$ is the adjustment for tax, $p_{Y t}$ is the price of output at the end of the period, and $\pi_{i t}$ is the rate of asset price inflation: $\pi_{i t}=\left(p_{i t}-p_{i, t-1}\right) / p_{i, t-1}$ where $p_{i t}$ is the asset price at the end of the period. Note that the required rate of return is assumed to be the same for all assets, since this is required for cost minimisation. If we assume that only $p_{Y t}$ and $p_{i t}$ are not known with certainty at the end of period $t-1$ and further that $E_{t-1}\left\{\pi_{i t}\left(p_{i, t-1} / p_{Y t}\right)\right\}=0$, then we can rewrite the ex ante user cost in simpler form:

$$
q_{i t}^{e}=T_{i t}\left[r_{t}^{*}+\delta_{i}\left(1+\pi_{i t}^{e}\right)-\pi_{i t}^{e}\right]\left(p_{i, t-1} / p_{Y t}^{e}\right), \quad i=1, \ldots, m
$$

where a superscript $e$ denotes the expectation as of the end of $t-1 .^{2}$ Firms are assumed to be price takers and to be risk-neutral. Hence they set the level of the stock of each asset so that the expected marginal product equals the expected real user cost. Firms must pick a level for the stock of each asset at the beginning of the period. Once this decision is made, the level of the stocks cannot be varied till the next period. But firms can adjust their other inputs, and consequently the output they supply, after prices and demand have been revealed. So this model, though very simple, does capture the twin notions that investment is carried out under uncertainty and that capital stocks cannot be adjusted instantaneously. ${ }^{3}$

I assume constant returns to scale and for ease of exposition that in addition to the $m$ capital goods there is only one other input ("labour"). I also assume that the production function is CES:

$$
Y_{t}=B_{t}\left[\sum_{i=1}^{m} a_{i} K_{i t}^{(\sigma-1) / \sigma}+a_{m+1} L_{t}^{(\sigma-1) / \sigma}\right]^{\sigma /(\sigma-1)}, \quad B_{t}>0, a_{i}>0, i=1, \ldots, m+1
$$

I use $1 / p_{Y T}^{e}$ as shorthand for $E_{t-1}\left\{1 / p_{Y t}\right\}$.

This model is essentially the same as the one considered by Berndt and Fuss (1986). In their model short period equilibrium is where capital stocks are pre-determined and firms adjust variable factors to maximise profits. 
where $Y_{t}$ is output, $B_{t}$ indexes the level of TFP, $K_{i t}$ is the flow of capital services from the $i$ th asset, and $L_{t}$ is labour; $\sigma>0$ is the elasticity of substitution. I consider below the effect on the results of using a more general production function. Capital services during period $t$ are assumed to be proportional to the stock $(A)$ at the beginning of the period (end of the period $t-1)$ :

$$
K_{i t}=A_{i, t-1}, \quad i=1, \ldots, m
$$

ie capital services during period $t$ are pre-determined (the constants of proportionality relating service flows to stocks are normalised to 1 ).

The expected, ex ante marginal product of the $i$ th asset is then

$$
E_{t-1}\left[\partial Y_{t} / \partial K_{i t}\right]=a_{i} E_{t-1}\left[B_{t}^{(\sigma-1) / \sigma} Y_{t}^{1 / \sigma}\right] / K_{i t}^{1 / \sigma}
$$

I assume that firms wish to minimise expected total costs for a given level of output. Expected total costs in real terms are given by

$$
E_{t-1}\left[w_{t} L_{t}+\sum_{i=1}^{m} q_{i t} K_{i t}\right]
$$

where $w_{t}$ is the real product wage. Minimisation of expected costs subject to (3) requires that

$$
a_{i} E_{t-1}\left[B_{t}^{(\sigma-1) / \sigma} Y_{t}^{1 / \sigma}\right] / K_{i t}^{1 / \sigma}=q_{i t}^{e} .
$$

Due to constant returns to scale this equation pins down only the output-capital ratios (or equivalently, the labour-capital ratios). To pin down the desired level of the capital stocks, firms also need to form expectations about (in this model) the price of output, the wage rate and the level of TFP in the next period. Given these, and some further assumption such as that the economy (or industry) is expected to be in long run equilibrium with price equal to average cost, the expected level of output is then determined. This closes the model and fixes the asset stocks: see (5). To the extent that expectations are not realised, in the next period 
firms will move up or down the short run supply curve for output, hence output and labour input may differ from what was expected when the levels of the capital stocks were fixed.

The short run demand curve for labour (conditional on output) comes from solving (3) for $L_{t}$ and using (4):

$$
L_{t}=a_{m+1}^{-\sigma /(\sigma-1)}\left[\left(Y_{t} / B_{t}\right)^{(\sigma-1) / \sigma}-\sum_{i=1}^{m} a_{i} A_{i, t-1}^{(\sigma-1) / \sigma}\right]^{\sigma /(\sigma-1)} .
$$

In the short run, variable costs are $W_{t} L_{t}$ where $W_{t}$ is the nominal wage. Once asset stocks have been chosen and after prices have been revealed, the firm maximises profit by equating price to marginal cost:

$$
d\left(W_{t} L_{t}\right) / d Y_{t}=p_{Y t}
$$

whence

$$
1=\left(w_{t} / a_{m+1}^{\sigma /(\sigma-1)}\right)\left(Y_{t}^{-1 / \sigma} / B_{t}^{(\sigma-1) / \sigma}\right)\left[\left(Y_{t} / B_{t}\right)^{(\sigma-1) / \sigma}-\sum_{i=1}^{m} a_{i} A_{i, t-1}^{(\sigma-1) / \sigma}\right]^{1 /(\sigma-1)}
$$

using (6). This relationship implicitly defines the short run supply curve for output, though no closed form solution for $Y$ is possible (except if $\sigma=1$, the Cobb-Douglas case).

The actual, ex post marginal product of the $i$ th type of capital is

$$
\partial Y_{t} / \partial K_{i t}=a_{i}\left(B_{t}^{(\sigma-1)} Y_{t} / K_{i t}\right)^{1 / \sigma}
$$

We can define the real, ex post user cost of capital $\left(q_{i t}\right)$ as equal to the ex post marginal product:

$$
q_{i t}=T_{i t}\left[r_{i t}+\delta_{i}\left(1+\pi_{i t}\right)-\pi_{i t}\right]\left(p_{i, t-1} / p_{Y t}\right)=a_{i}\left(B_{t}^{(\sigma-1)} Y_{t} / K_{i t}\right)^{1 / \sigma}, \quad i=1, \ldots, m
$$

where $\pi_{i t}$ is the realised rate of asset price inflation and $r_{i t}$ is the ex post rate of return. This last equation could be thought of as an implicit definition of the ex post rate of return: if we knew the parameters of the production function (the $\alpha_{i}$ 's), we could solve for the rates of return (the $r_{i t}$ 's), assuming that all the other elements of the user cost are known. Note that here we do not assume that the ex post rate of return is equalised across assets, so we write 
$r_{i t}$, not $r_{t}$. In fact we shall show in a moment that in general ex post rates of return will differ as between assets, even though ex ante they are the same.

From the point of view of growth accounting, we should construct our capital services aggregate using the actual (ex post) marginal products (Berndt and Fuss, 1986; Berndt, 1990). This is because, under the assumptions of perfect competition on both the output and input sides, the basic growth accounting equation holds in this model. From (3):

$$
\begin{aligned}
\frac{d \ln B_{t}}{d t} & =\frac{d \ln Y_{t}}{d t}-\frac{L_{t}}{Y_{t}} \frac{\partial Y_{t}}{\partial L_{t}} \frac{d \ln L_{t}}{d t}-\sum_{i=1}^{m} \frac{K_{i t}}{Y_{t}} \frac{\partial Y}{\partial \ln K_{i t}} \frac{d \ln K_{i t}}{d t} \\
& =\frac{d \ln Y_{t}}{d t}-\left(1-\frac{S_{t}}{Y_{t}}\right) \frac{d \ln L_{t}}{d t}-\left(\frac{S_{t}}{Y_{t}}\right) \sum_{i=1}^{m} \frac{q_{i t} K_{i t}}{S_{t}} \frac{d \ln K_{i t}}{d t}
\end{aligned}
$$

where $S_{t}$ is aggregate profit (gross operating surplus) deflated by the price of output. So if there were only one type of capital, there would be no difficulty in estimating TFP growth from the right hand side of this equation, employing a discrete approximation such as the Törnqvist. We would just use the share of profit in the value of output to measure the elasticity of output with respect to capital. But if there is more than type of capital, how are we to measure the elasticity of output with respect to each type separately?

To answer this question, we can note three implications of our model:

1. By definition, the (true) ex post user cost equals the marginal product. So this is the measure we want to use in an index of capital services, leaving aside for the moment how to measure user costs in practice. A Törnqvist index of the growth of aggregate capital services $(K)$ can be written as:

$$
\ln \left[K_{t} / K_{t-1}\right]=\sum_{i=1}^{m}(1 / 2)\left(v_{i t}+v_{i, t-1}\right) \ln \left[K_{i t} / K_{i, t-1}\right]
$$

where

$$
v_{i t}=q_{i t} K_{i t} / \sum_{i=1}^{m} q_{i t} K_{i t}
$$

We can also note that, under the assumption of constant returns to scale, the sum across assets of the returns equals aggregate real profit: 


$$
S_{t}=\sum_{i=1}^{m} q_{i t} K_{i t},
$$

a relationship used in (10) above.

2. The ex ante and ex post user costs, and the ex ante and ex post marginal products, are proportional to each other and the factor of proportionality is the same for all assets:

$$
\frac{q_{i t}^{e}}{q_{i t}}=\frac{E_{t-1}\left[B_{t}^{(\sigma-1) / \sigma} Y_{t}^{1 / \sigma}\right]}{B_{t}^{(\sigma-1) / \sigma} Y_{t}^{1 / \sigma}}, \quad i=1, \ldots, m,
$$

using (5). This means that we could equally well use the ex ante user costs in place of the ex post ones for the weights in the index of capital services since

$$
v_{i t}=q_{i t} K_{i t} / \sum_{i=1}^{m} q_{i t} K_{i t}=q_{i t}^{e} K_{i t} / \sum_{i=1}^{m} q_{i t}^{e} K_{i t}=v_{i t}^{e} \text { (say), } \quad i=1, \ldots, m .
$$

However, even if we use ex ante weights in constructing the index of capital services, we should still use the ex post profit share $(S / Y)$ as the weight to apply to that index when estimating TFP growth: see (10) above. So the contribution of capital to output growth, using for example a Törnqvist index, is

$$
(1 / 2)\left[\left(S_{t} / Y_{t}\right)+\left(S_{t-1} / Y_{t-1}\right)\right] \ln \left[K_{t} / K_{t-1}\right]
$$

with the weights in the capital services index measured either by (11) or (14).

3. Ex ante profits are $S_{t}^{e}=\sum_{i=1}^{m} q_{i t}^{e} K_{i t}$ and these stand in the same proportion to ex post profits as do ex ante to ex post user costs:

$$
S_{t}^{e}=\sum_{i=1}^{m} q_{i t}^{e} K_{i t}=\frac{E_{t-1}\left[B_{t}^{(\sigma-1) / \sigma} Y_{t}^{1 / \sigma}\right]}{B_{t}^{(\sigma-1) / \sigma} Y_{t}^{1 / \sigma}} S_{t} .
$$


These results have been established for a CES production function with only one variable input. But still sticking with CES, equation (13) would continue to hold whatever the number of variable inputs. However, dropping the CES assumption and assuming a general neoclassical production function would change the results (even with constant returns to scale). For example, with a translog production function, the ratio of expected to actual marginal products would no longer be the same for all assets, ie (13) would not hold. But the difference between the CES and translog cases depends on the share elasticity parameters which may in practice be small (see Annex A). If so, the CES assumption could still be defended as a good approximation in this context. Note that we only need the CES to be a good approximation for two consecutive points; we do not need to assume that the same CES production function holds at all points.

\section{Measuring user costs in practice}

Now we consider how ex ante and ex post user costs can be estimated in practice. Tax factors, asset prices and the output price are directly observable, at least in principle. Depreciation rates present more of a problem but for the present purpose we ignore this and assume that data on these are available too.

\subsection{Ex ante user costs}

To estimate the ex ante user cost we require one-period-ahead forecasts of the asset price and the output price: see equation (1). These could be generated univariate time series models (Harper et al, 1989). In addition, we need the required rate of return. This could be taken from financial market data. Diewert (2001) suggests using a constant real interest rate of $4 \%$ per annum (which he argues suits the OECD experience) plus the actual rate of consumer price inflation. However, there are advantages in not having to resort to extraneous data, especially if we are trying to develop methods that could be applied in practice by statistical agencies. An alternative, two step procedure requires only the data used in the ex post method. First, define the weighted average actual rate of return $\left(\bar{r}_{t}\right)$ as: 


$$
\overline{r_{t}}=\frac{\sum_{i=1}^{m}\left(T_{i t} p_{i, t-1} A_{i, t-1}\right) r_{i t}}{\sum_{i=1}^{m} T_{i t} p_{i, t-1} A_{i, t-1}}
$$

where the weights are asset values (adjusted for tax). Then we can solve for this average rate of return using equations (12) and (4):

$$
\bar{r}_{t}=\frac{p_{Y t} S_{t}-\sum_{i=1}^{m} T_{i t} p_{i, t-1} A_{i, t-1}\left[\delta_{i}\left(1+\pi_{i t}\right)-\pi_{i t}\right]}{\sum_{i=1}^{m} T_{i t} p_{i, t-1} A_{i, t-1}} .
$$

Note that this is not the same as assuming that the ex post rates of return are the same for all assets. However, were we to make that assumption (ie $r_{i t}=r_{t}, i=1, \ldots, m$ ), then the common rate of return would also be given by the right hand side of (17). The second step is to form a forecast of this average rate. We then have all the information needed to calculate the ex ante user costs. The justification of this procedure is as follows. The average, ex post rate of return must bear some relation to the rate of return required ex ante. Firms would not go on investing indefinitely if they expected the actual rate to be below the required one. Hence an econometric estimate of the required rate should be extractible from the average rate experienced in practice. ${ }^{4}$

\subsection{Ex post user costs}

As noted above, if there were only one asset then calculating the ex post user cost would present no difficulty. We could just use total profit as the weight for capital in the growth accounting calculation. But in practice there are many assets, which leaves the problem of how to in effect divide up profit amongst the assets. The usual way to calculate ex post user costs is to assume that the rate of return is the same for all assets; this rate can then be found by solving equation (12), since aggregate profit is observed. (The solution is given by the right hand side of equation (17), but with a different interpretation). Using this solution together with the other known data, the ex post user costs can then be calculated. This method has been used by Christensen and Jorgenson (1969) and Jorgenson, Gollop and Fraumeni

\footnotetext{
4 Harper et al (1989) use an ARIMA model to estimate expected asset price inflation in some of their variants, as recommended by Diewert (1980). But no-one seems to have used any such method to estimate the rate of return.
} 
(1987), who have been followed by many other researchers, eg Oulton and Srinivasan (2003) and O'Mahony and van Ark (2003); it is also used by the Bureau of Labor Statistics and the Australian Bureau of Statistics to produce official estimates on an ongoing basis. The difficulty here is that the assumption of a common rate of return ex post cannot be justified in general. In fact we can prove a proposition:

PROPOSITION. In the model set out above, and in the absence of a numerical fluke, the ex post rate of return will be the same for all assets if and only if all expectations (for asset prices, output price and output) are satisfied, in which case the ex post and ex ante rates of return are equal.

The proof is in the Annex. The intuition behind the proof is as follows. We have just shown that ex ante and ex post user costs are proportional to each other. But the rate of return element as a proportion of the user cost varies between assets. So there is no way that the ex post rates of return can all be equal and so proportional to the ex ante rate unless there are offsetting differences between the expected and actual rates of asset price inflation. But if such differences occurred they would be just a numerical fluke.

\section{A numerical example}

We illustrate these ideas by means of a numerical example based on a three-input CES production. The first input represents non-ICT capital, the second ICT capital and the third labour. We calibrate the parameters of the production function so that the results match with observation in two respects: first, in long run equilibrium the model should correctly predict the average income share of capital, which we set at $40 \%$, and second, it should give a plausible value for the share of gross operating surplus attributable to ICT capital, which we set at $15 \%$.

We also fix the ex ante real user costs at realistic values:

$$
q_{1 t}^{e}=0.152, q_{1 t}^{e}=0.510
$$

These values derive from (2) with the following assumptions on the underlying variables: 


$$
\delta_{1}=0.10, \delta_{2}=0.30, \pi_{1 t}^{e}=0.02, \pi_{2 t}^{e}=-0.20, r_{t}^{*}=0.07, T_{1 t}=T_{2 t}=1
$$

together with the following normalisations:

$$
p_{Y t}^{e}=p_{1, t-1}^{A}=p_{2, t-1}^{A}=1
$$

We also normalise the expected level of TFP $\left(B_{t}\right)$ to equal one. Finally, due to the assumption of constant returns to scale, the expected level of output is indeterminate without imposing some further structure on the model. So we tie this down by fixing the expected level of labour input exogenously. We normalise this level to equal one.

As shown in Annex B, fixing the two ex ante user costs implies a value for the expected real wage as a function of these and of the parameters of the production function (the $a_{i}$ and $\sigma)$. Annex B also shows that we can solve for the $a_{i}$ as a function of the user costs, the income share of capital, the share of ICT in profits, and the elasticity of substitution. In other words, the two user costs, the two empirically-given shares, and the elasticity of substitution (which we allow to take a range of values) determine everything else.

We now employ these values to solve for the equilibrium levels of asset stocks. We then consider the effect of a shock to the real wage which puts a wedge between actual and expected output and labour input, while assuming that expectations of real asset prices are correct. $^{5}$ The size of the shock is such as either to lower output by $50 \%$ below or to raise it by $50 \%$ above the expected (equilibrium) level. We compare the ex ante user costs with both the true ex post costs and the ex post costs calculated on the (erroneous) basis of a common rate of return. ${ }^{6}$ Finally, we also calculate the growth of the index of capital services and the contribution of capital to growth on an ex ante basis, an incorrect ex post basis, and a true ex post basis; for these calculations we assume that non-ICT capital is growing at $4 \%$ per period and ICT capital at $20 \%$ per period. $^{7}$

\footnotetext{
$5 \quad$ TFP shocks would generate qualitatively similar results but these are harder to calculate since there is no closed form solution for the short run supply curve, equation (7).

$6 \quad$ Berndt and Fuss (1986) and Harper et al (1989) presented estimates of aggregate TFP growth in the U.S. using what is called here the ex ante and ex post (common) methods, but not the ex post (true) method.

7 These calculations employ Törnqvist indices as in equations (11) and (15), with appropriate definitions of the user costs. In calculating the contribution of capital we assume that the profit share in period $t-1$ is the equilibrium one.
} 
The results appear in Table 1, for three different values of the elasticity of substitution: 0.5 , 1.0 (the Cobb-Douglas case) and $1.5 .^{8}$ We can see that the true ex post user costs differ substantially from the ex ante user costs and to a lesser extent from the ex post user costs calculated on the assumption of a common rate of return for both assets, the "ex post (common)" estimates. The reason is that, in the face of these shocks, the true ex post rates of return differ substantially between the two assets: eg with $\sigma=0.5$ and for the negative shock, the true rate of return on non-ICT assets is $-4.4 \%$ while that on ICT assets is $-31.3 \%$, even though investment decisions were made on the basis of a common required rate of return of $+7 \%$. The ex post (common) method also makes some large errors in estimating the growth of capital services, particularly so if $\sigma=0.5$ when the errors range from 0.8 to $2.4 \%$. The ex ante method, as we already know, makes no errors here. ${ }^{9}$ But when we come to compare the errors made by the ex ante and ex post (common) methods in estimating the contribution of capital to growth, the picture is not so clear (Table 2). Of course, for $\sigma=1.0$, the ex ante method is necessarily better since in this case the profit share is constant and unaffected by shocks. But when $\sigma=0.5$, the ex ante method is better with a negative shock but worse with a positive shock. And when $\sigma=1.5$, the ex post (common) method does better for both positive and negative shocks. It is also interesting to note that the ex post (common) method overstates the true contribution for negative shocks, and understates it for positive shocks, while the ex ante method has the opposite pattern of errors.

These simulations have the advantage that the different methods can be compared against the correct answer, given by the "ex post (true)" method. On the other hand, they may stack the deck against the ex post (common) method, since we are taking ex ante user costs as known with certainty, whereas in practice this is not the case. I therefore turn next to a comparison between the methods using real data.

\footnotetext{
8 The case where $\sigma>1$ might be thought less relevant empirically since this implies that the profit share rises in a recession.

When applied by econometricians and statisticians in practice, the ex ante method would of course not be exact, if only because firms' expectations cannot be observed without error.
} 


\section{How much difference does method make? A check using UK data}

\subsection{Data and methods}

I employ the Bank of England Industry Dataset (BEID) to estimate the growth of capital services and the contribution of capital by four different methods. The BEID provides data on real and nominal investment in seven types of asset, three ICT and four non-ICT, for each of 34 industries covering the whole economy over the period 1948-2000 inclusive: see Oulton and Srinivasan (2005) for full details. The asset types together with the depreciation rates that I used are as follows:

\begin{tabular}{|l|c|}
\hline Asset & Depreciation rate, \% per annum \\
\hline Structures & 2.5 \\
\hline Plant and machinery (excluding ICT) & 13.0 \\
\hline Vehicles & $25.0^{10}$ \\
\hline Intangibles (excluding software) & 13.0 \\
\hline Computers & 31.5 \\
\hline Software & 31.5 \\
\hline Communications equipment & 11.0 \\
\hline
\end{tabular}

These depreciation rates are comparable to those employed by the U.S. Bureau of Economic Analysis and by most U.S. researchers. I exclude three industries that are largely in the public sector, accounting for around 20\% of GDP: Public administration \& defence, Education, and Health \& social work. For these the measures of gross operating surplus are not very meaningful. ${ }^{11}$ The 31 remaining industries constitute what I call the market sector.

The actual period of the analysis was 1970-2000, since the data for value added and gross operating surplus are for this period. Investment data for the years 1948-1969 were used to generate the capital stocks at the beginning of 1970, in conjunction with estimates of the starting stocks at the beginning of 1948. For two of the ICT assets - computers and software

10 Except for investment in vehicles by the transport industries: Rail transport (5.89\%), Water transport $(6.11 \%)$, and Air transport (8.25\%).

${ }_{11}$ Obviously, most output in the public sector is not sold to consumers at a market price. So GOS cannot be calculated as revenues minus labour and intermediate costs. Instead in the national accounts GOS is calculated as depreciation on the estimated stocks of assets, with no allowance for a return to capital. 
- nominal investment was deflated by official US price indices, adjusted for exchange rate changes. For the other assets, I employed official UK price indices as deflators.

The starting point for each method is estimates of capital stocks for each of the seven asset types. These are generated from the investment data by assuming that depreciation is geometric.

Capital services were then estimated by four methods: (1) ex post; (2) ex ante (perfect foresight); (3) ex ante (AR); and (4) hybrid. Under the ex post method we solve for the unknown common rate of return. The returns to the assets then by definition sum to observed gross operating surplus (GOS). ${ }^{12}$ Under the two ex ante methods, we use an estimate of the required rate of return in the user cost formula. For the perfect foresight variant, we assume that expectations of prices are correct; for the AR variant, we forecast prices using ARMA models. For both variants, we employ predicted, not actual, GOS to calculate capital contributions. In the hybrid method we use the ex ante (AR) method to estimate capital services but actual profit to calculate contribution. See Table 3 for more detail. The hybrid method is the closest we can get to what was called "ex post (true)" in the previous section. It differs from the latter to the extent that there are errors in the estimates of the required rate of return or of price expectations.

\section{Ex post}

The first step was to estimate the nominal rate of return and the user costs for each of the seven assets, for each of the 31 industries, using the ex post method. It is also helpful for analytical purposes to calculate real rates of return, defined as the nominal rate for each industry minus the growth rate of an appropriate price index. For the latter I used the same price index for each industry, namely the implicit deflator for GDP in the market sector. This was estimated as a Törnqvist index of the implicit deflators for value added in each industry (the weights were nominal value added); data again came from the BEID.

As a diagnostic tool I first derive the nominal rate of return in the market sector as a whole (ie using aggregate data). The corresponding real rate is shown in Fig. $1 .^{13}$ The mean of this rate over $1970-2000$ was $8.66 \%$ p.a. The rate of return is clearly quite volatile (the standard deviation is 3.96) and shows steep declines in the major recessions (1975-6, 1981-82, and

12 Gross operating surplus was adjusted to remove mixed income and the portion estimated to be the return to holding inventories.

13 The real rate $\left(R_{t}\right)$ is calculated by the formula: $R_{t}=\left[\left(1+r_{t}\right) /\left(1+\pi_{t}\right)\right]-1$, where $r_{t}$ is the ex post nominal rate of return and $\pi_{t}$ is the (discrete) growth rate of the GDP deflator, both in the market sector. 
1991-92). Also, it appears to show no trend. After some experimentation with ARMA models, an $\mathrm{AR}(2)$ model was found to fit well and displayed white noise errors (here $R$ is the real rate of return in the market sector and $z$ statistics are in parentheses):

$$
R_{t}=0.0830+0.9040 R_{t-1}-0.6202 R_{t-2}+\text { error }
$$

Period: $1972-2000, \mathrm{~N}=29$, see $=0.0260$

Tests that errors are white noise:

$$
\begin{aligned}
& \text { Bartlett's B statistic }=0.5605, \text { probability }>B=0.91 \\
& \text { Ljung-Box Q statistic }=7.8587 \text {, probability }>Q=0.80
\end{aligned}
$$

I next calculated the ex post real rate of return in each industry separately and then for each industry the time mean of these rates. Due to differences in risk, one would not expect the mean return to be the same in all industries. But the standard deviation across the 31 industries of the time means is very high, $11.72 \%$ p.a., indicating persistent differences over a thirty-one year period that seem implausibly high. ${ }^{14}$

A check on the validity of the ex post method is given by looking at the number of negative user costs that the method generates. These came to 116 over the analysis period, out of a total number of user costs of $6727(=31$ industries $x 7$ assets $x 31$ years) or $1.7 \% .101$ of the 116 occurred for buildings, mostly in the period 1970-81, and most of these in a small number of industries with negative rates of return (industries 3, 10, 22 and 24). The reason is that, particularly in the years 1970-81, the buildings price index rose particularly rapidly (at times at $20 \%$ p.a. or more) while the depreciation rate for buildings is low (2.5\% p.a.).

\section{Ex ante method: perfect foresight of prices}

The first issue here is picking an ex ante rate of return. The simplest choice is the mean rate in the market sector as a whole, $8.66 \%$ p.a. in real terms. As we have seen (Fig. 1), there is no trend in this rate over our period. Another possibility is to use the rate predicted by the $\operatorname{AR}(2)$ model. However this would be quite variable and even at times negative. A justification for using the mean rate is that investments cannot be unwound over a horizon as short as a year, hence a one-year rate of return is not appropriate. After all, the theory is based on the concept

14 Excluding two outliers reduces the standard deviation to $6.30 \%$ p.a., still an implausibly large number. The wide variation in the mean rates of return could be due to a number of causes, such as inaccurate allowance at the industry level for mixed income and inventory holding, differences across industries in depreciation rates, or unmeasured intangible assets (eg R\&D stocks). 
of investors looking ahead one period, but the theory has nothing to say about how long such a period is in practice. A second possibility is to use the mean rate for each industry, since industries may be subject to different degrees of risk. Unfortunately, this founders on the finding above that some industry rates are implausibly low or high. So I use the mean rate in the market sector as a whole.

Perfect foresight for prices means using actual asset prices to calculate the capital gain term in the user cost of capital formula and using the actual rate of inflation in the market sector to construct the nominal rate of return from the (constant) real one. Applying this method, I found that now only 50 user costs are negative, $0.7 \%$ of the total. Of these 40 are for buildings in 1973-74. So use of the ex ante rate has more than halved the number of negative user costs.

\section{Ex ante method: ARMA forecasts of asset prices}

Perfect foresight for prices is not very plausible, so the next step is to use forecasts of prices in the user cost formula. I continue to assume that the required, real rate of return is the same for all industries and constant over time. And as before the required nominal rate varies over time (though not across industries) since firms have to estimate the rate of inflation. I model the rate of inflation as an ARMA process, but with year dummies for the oil price shocks. Arguably, the oil price hikes of 1974 and 1979 (which caused spikes in inflation one year later) led to firms anticipating more rapid inflation; without these dummies an ARMA process tends always to lag behind actual inflation (whether in periods of rising or falling inflation). I found that an AR(2) model with year dummies for 1975 and 1980 produced satisfactory results for the market sector GDP deflator. "Satisfactoriness" was tested (a) by the significance of the coefficients and (b) by whether the errors were white noise using the Bartlett and Ljung-Box tests. ${ }^{15}$

I model asset price inflation as ARMA processes for the growth of relative asset prices, ie the growth of asset prices minus the growth of the GDP deflator for the market sector. Either an $\mathrm{AR}(2)$ or an $\mathrm{AR}(1)$ model worked quite well. In no case did an MA element turn out to play a significant role.

15 I used Stata's arima command, which does ML estimates of ARMA models. In many industries, changes in the relative prices of plant and machinery are insignificant, ie these prices rise at the same rate as the GDP deflator. 
Using forecasts of prices I now find that there are no longer any negative user costs. So compared with the ex post method, the combined use of a fixed real rate of return and forecasted, not actual, prices has completely eliminated the problem of negative user costs.

\section{Hybrid method}

I continue to use the AR models to forecast prices and assume the same required real rate of return, $8.66 \%$ p.a. But in estimating the contribution of capital to growth I now use actual GOS, not predicted GOS.

\subsection{Results}

How sensitive are the industry-level growth rates of capital to the method employed? The answer is, in most cases not very much: see Table 3. However, in the case of some important industries such as finance and business services the difference can be substantial.

Next let us consider results for the market sector as a whole (Table 3). These are derived by aggregating over the industry-level results:

$$
\hat{K}_{t}=\sum_{j=1}^{n} G O S_{j} * \hat{K}_{j t} / \sum_{j=1}^{n} G O S_{j}
$$

That is, the growth of capital services in the market sector $\left(\hat{K}_{t}\right)$ is a Divisia (in practice a Törnqvist) index of the $n$ industry-level capital growth rates $\left(\hat{K}_{j t}\right.$, calculated in accordance with equation (11) above), where the weights are industry profit $\left(G O S_{j}\right)$ and $n=31$. Both the weights and the industry-level indices vary with the method. For the ex post and hybrid methods the weights are actual GOS; for the ex ante methods, they are predicted GOS. To obtain the contribution of capital to output growth in the market sector, I weight the growth of capital services in the market sector by the share of profit in market sector value added. The profit share is the actual one for the ex post and hybrid methods; for the other methods it is the expected share (ie expected profit over actual value added). ${ }^{16}$

\footnotetext{
16 In order to make the comparison at all, it is necessary to eliminate the negative user costs. Otherwise it is not possible in some cases to calculate the industry-level index of capital services. In any case, negative user costs make no sense economically. I eliminate negative user costs when they occur by setting the real rate of return equal to the market sector average and setting the real capital gain part of the user cost formula to zero.
} 
Both the growth rate of capital services and the contribution of capital are strongly affected by the method used (Table 4 and Figures 2, 3 and 4). The largest difference is between the ex ante (AR) and the hybrid methods, more than one percentage point per annum averaged over 1970-2000, though since 1992 the four methods show similar growth rates (Figure 2). Why is the difference so large? The answer is that in calculating the market sector index for capital services the different methods apply different weights to the industry-level indices. The ex post and hybrid methods use actual profits, the others use expected profits. It turns out that the industry growth rates are more strongly correlated with actual profit than they are with predicted profit. The cross-industry correlation coefficient of the ex ante (AR) measure of capital services growth with actual profit is 0.26 but with predicted profit it is only 0.19 . The economic reason for this is that the ex post rate of return (and hence ex post profits) and the growth rate of capital are positively correlated. If we exclude two outliers, industries 2 (Oil \& gas) and 18 (Construction), the correlation is +0.31 (Figure 5). So use of actual rather than predicted profit tends to increase the weight on fast-growing industries, thus raising the average.

In summary, when we aggregate up from the industry-level estimates to the market sector as a whole, the method used makes a substantial difference. The main reason is that industries with high ex post rates of return tend to have high growth rates of capital.

\section{Conclusions}

We have established the following results:

1. Ex post user costs are in principle the correct weights to employ in constructing an index of capital services.

2. The usual method of estimating ex post user costs, which assumes a common ex post rate of return, is not in principle correct, since ex post the rates of return typically differ between assets, unless expectations are fully realised.

3. Ex ante user costs are proportional to true ex post user costs and the factor of proportionality is the same for all assets, under the assumption that the production function is CES. Hence ex ante user costs can in this case be validly employed as the weights in the index of capital services. 
4. Whether ex post or ex ante user costs are used to construct the index of capital services, the growth of this index should be weighted by the actual (ex post), observed share of profits in output, when we come to calculate the contribution of capital to output growth.

5. The components of the ex ante user costs that are not known in advance with certainty or not directly observed by the econometrician - future asset and output prices and the required rate of return - can all be estimated from the same data as are typically used to estimate ex post user costs, namely actual prices plus an estimate of the ex post average rate of return (though extraneous data from financial markets could also be used for estimating the required rate of return).

6. Once ex ante user costs have been estimated, ex post user costs (consistent with the ex ante ones) can also be derived and the latter will by definition add up to observed aggregate profit (gross operating surplus).

Numerical simulation using a three-input CES production function suggests that either the ex post (common) or the ex ante method could be closer to the truth. But the ex post method may be superior when calculating the contribution of capital (except in the Cobb-Douglas case). These simulations assume no error in calculating expectations or the required rate of return. Our empirical results using UK industry data suggest that at the industry level the growth rates of capital services are insensitive to the method employed, except in a few cases. The ex post method also produces a significant number of economically impossible, negative user costs. But when we aggregate up from the industry-level estimates to the market sector as a whole, the method used makes a substantial difference. Now the hybrid method produces substantially higher estimates of the growth rate of capital, and also of the contribution of capital to growth, than do the ex ante methods (the difference with the ex post method is less stark). The main reason is that industries with high ex post rates of return tend to have high growth rates of capital.

In summary, both theory and empirical tests favour the hybrid method which requires three steps. First, estimate the unobserved elements of the ex ante user costs using observed data on the average, ex post rate of return, and asset and output prices. Estimation could be by single equation methods (as here) or conceivably by a reduced form VAR. Second, calculate the growth of capital services using these estimated ex ante user costs as weights. Finally, calculate the contribution of capital to output growth by the growth of capital services weighted by the observed, ex post profit share. This hybrid method has the advantage of 
employing exactly the same data as is required for the usual ex post measures and hence could be readily implemented by national statistical agencies. 
Table 1

User costs, growth of capital, and contribution of capital to growth: simulation of three-input CES production function

\begin{tabular}{|c|c|c|c|c|c|c|c|}
\hline \multirow{3}{*}{\multicolumn{2}{|c|}{ Shock }} & \multicolumn{6}{|c|}{ Elasticity of substitution } \\
\hline & & \multicolumn{2}{|c|}{$\sigma=0.5$} & \multicolumn{2}{|c|}{$\sigma=1.0$} & \multicolumn{2}{|c|}{$\sigma=1.5$} \\
\hline & & 0.5 & 1.5 & 0.5 & 1.5 & 0.5 & 1.5 \\
\hline \multirow{3}{*}{$\begin{array}{l}\text { User costs: } \\
\text { asset } 1\end{array}$} & Ex ante: $q_{1 t}^{e}$ & 0.152 & 0.152 & 0.152 & 0.152 & 0.152 & 0.152 \\
\hline & Ex post (common) & 0.025 & 0.364 & 0.067 & 0.237 & 0.089 & 0.205 \\
\hline & Ex post (true): $q_{1 t}$ & 0.038 & 0.342 & 0.076 & 0.228 & 0.096 & 0.199 \\
\hline \multirow{3}{*}{$\begin{array}{l}\text { User costs: } \\
\text { asset } 2\end{array}$} & Ex ante: $q_{2 t}^{e}$ & 0.510 & 0.510 & 0.510 & 0.510 & 0.510 & 0.510 \\
\hline & Ex post (common) & 0.383 & 0.722 & 0.425 & 0.595 & 0.447 & 0.563 \\
\hline & Ex post (true): $q_{2 t}$ & 0.128 & 1.148 & 0.255 & 0.765 & 0.321 & 0.668 \\
\hline \multirow[t]{2}{*}{ Profit share } & Ex ante: $S_{t}^{e} / Y_{t}^{e}$ & 0.400 & 0.400 & 0.400 & 0.400 & 0.400 & 0.400 \\
\hline & Ex post: $S_{t} / Y_{t}$ & 0.200 & 0.600 & 0.400 & 0.400 & 0.504 & 0.349 \\
\hline \multirow{4}{*}{$\begin{array}{l}\text { Rates of } \\
\text { return }\end{array}$} & Required: $r_{t}^{*}$ & 0.070 & 0.070 & 0.070 & 0.070 & 0.070 & 0.070 \\
\hline & Ex post (common): $r_{t}$ & -0.057 & 0.282 & -0.015 & 0.155 & 0.007 & 0.123 \\
\hline & Ex post (true): $r_{1 t}$ & -0.044 & 0.260 & -0.006 & 0.146 & 0.014 & 0.117 \\
\hline & Ex post (true): $r_{2 t}$ & -0.313 & 0.708 & -0.185 & 0.325 & -0.119 & 0.228 \\
\hline \multirow{2}{*}{$\begin{array}{l}\text { Weight in } \\
\text { capital } \\
\text { services } \\
\text { index: } \\
\quad \text { asset } 1\end{array}$} & $\begin{array}{l}\text { Ex ante and ex post } \\
\text { (true): } v_{1 t}^{e} \text { and } v_{1 t}\end{array}$ & 0.850 & 0.850 & 0.850 & 0.850 & 0.850 & 0.850 \\
\hline & Ex post (common) & 0.700 & 0.878 & 0.800 & 0.867 & 0.821 & 0.862 \\
\hline \multirow{2}{*}{$\begin{array}{l}\text { Weight in } \\
\text { capital } \\
\text { services } \\
\text { index: } \\
\quad \text { asset } 2\end{array}$} & $\begin{array}{l}\text { Ex ante and ex post } \\
\text { (true): } v_{2 t}^{e} \text { and } v_{2 t}\end{array}$ & 0.150 & 0.150 & 0.150 & 0.150 & 0.150 & 0.150 \\
\hline & Ex post (common) & 0.300 & 0.122 & 0.200 & 0.133 & 0.179 & 0.138 \\
\hline \multirow{2}{*}{$\begin{array}{l}\text { Growth of } \\
\text { capital } \\
\text { services } \\
\text { index, \% pa }\end{array}$} & $\begin{array}{l}\text { Ex ante and } \\
\text { ex post (true) }\end{array}$ & 6.40 & 6.40 & 6.40 & 6.40 & 6.40 & 6.40 \\
\hline & Ex post (common) & 8.80 & 5.96 & 7.20 & 6.13 & 6.87 & 6.21 \\
\hline \multirow{3}{*}{$\begin{array}{l}\text { Contribution } \\
\text { of capital, } \\
\% \text { pa }\end{array}$} & Ex ante & 2.56 & 2.56 & 2.56 & 2.56 & 2.56 & 2.56 \\
\hline & Ex post (common) & 2.64 & 2.98 & 2.88 & 2.45 & 3.11 & 2.33 \\
\hline & Ex post (true) & 1.92 & 3.20 & 2.56 & 2.56 & 2.89 & 2.40 \\
\hline
\end{tabular}

Note See text and Annex B for explanation. Asset 1 is non-ICT capital, asset 2 is ICT capital; third input is labour. Shock: a proportionate shock to output; actual output is either $50 \%$ or $150 \%$ of the expected level. "Ex post (common)": a statistic estimated under the assumption that the ex post rate of return is the same for both assets. Growth of capital services assumes that the stock of asset 1 has grown at $4 \%$ and that of asset 2 at $20 \%$. 
Table 2

Errors in estimating the contribution of capital to growth, \% pa: comparison of ex ante and ex post (common) methods

\begin{tabular}{|l|c|c|c|c|c|c|}
\hline \multirow{2}{*}{} & \multicolumn{9}{c|}{ Elasticity of substitution } \\
\cline { 2 - 7 } & \multicolumn{2}{|c|}{$\sigma=0.5$} & \multicolumn{2}{c|}{$\sigma=1.0$} & \multicolumn{2}{c|}{$\sigma=1.5$} \\
\hline Shock & 0.5 & 1.5 & 0.5 & 1.5 & 0.5 & 1.5 \\
\hline Ex ante & $\mathbf{0 . 6 4}$ & -0.64 & $\mathbf{0 . 0 0}$ & $\mathbf{0 . 0 0}$ & -0.33 & 0.16 \\
\hline Ex post (common) & 0.72 & $\mathbf{- 0 . 2 2}$ & 0.32 & -0.11 & $\mathbf{0 . 2 1}$ & $\mathbf{- 0 . 0 7}$ \\
\hline
\end{tabular}

Note Derived from lowest panel of Table 1. Error is estimated contribution minus true one. Smallest absolute errors shown in bold. 
Table 3

Comparison of methods of estimating capital services and the contribution of capital

\begin{tabular}{|l|l|l|l|l|}
\hline Method & Rate of return & Prices & $\begin{array}{l}\text { Weights in capital } \\
\text { services } \\
\text { index }\end{array}$ & $\begin{array}{l}\text { Weight for } \\
\text { contribution } \\
\text { of capital }\end{array}$ \\
\hline $\begin{array}{l}\text { Ex post, } \\
\text { common }\end{array}$ & $\begin{array}{l}\text { Ex post, same } \\
\text { for all assets; } \\
\text { differs across } \\
\text { industries }\end{array}$ & Actual & $\begin{array}{l}\text { Returns to assets } \\
\text { estimated using } \text { ex post } \\
\text { rate of return and actual } \\
\text { prices; returns sum to } \\
\text { actual, observed GOS }\end{array}$ & $\begin{array}{l}\text { Observed } \\
\text { GOS }\end{array}$ \\
\hline $\begin{array}{l}\text { Ex ante, } \\
\text { perfect } \\
\text { forecast }\end{array}$ & $\begin{array}{l}\text { Derived } a \\
\text { priori, same for } \\
\text { all assets }\end{array}$ & $\begin{array}{l}\text { Actual } \\
\text { (expectations } \\
\text { assumed } \\
\text { correct) }\end{array}$ & $\begin{array}{l}\text { Returns to assets } \\
\text { estimated using } \text { ex ante } \\
\text { rate of return and } \text { actual } \\
\text { prices; returns do } \text { not } \text { sum } \\
\text { to observed GOS }\end{array}$ & $\begin{array}{l}\text { Predicted } \\
\text { GOS }\end{array}$ \\
\hline $\begin{array}{l}\text { Ex ante, } \\
\text { ARMA }\end{array}$ & $\begin{array}{l}\text { Derived } a \\
\text { priori, same for } \\
\text { all assets }\end{array}$ & $\begin{array}{l}\text { Forecast by } \\
\text { ARMA model }\end{array}$ & $\begin{array}{l}\text { Returns to assets } \\
\text { estimated using } \text { ex ante } \\
\text { rate of return and } \\
\text { predicted } \text { prices; returns } \\
\text { do } \text { not } \text { sum to observed } \\
\text { GOS }\end{array}$ & $\begin{array}{l}\text { Predicted } \\
\text { GOS }\end{array}$ \\
\hline $\begin{array}{l}\text { Ex ante, } \\
\text { hybrid }\end{array}$ & $\begin{array}{l}\text { Derived } a \\
\text { priori, same for } \\
\text { all assets }\end{array}$ & $\begin{array}{l}\text { Forecast by } \\
\text { ARMA model }\end{array}$ & $\begin{array}{l}\text { ditto, except that returns } \\
\text { sum to observed GOS }\end{array}$ & $\begin{array}{l}\text { Observed } \\
\text { GOS }\end{array}$ \\
\hline
\end{tabular}




\section{Table 4}

Mean growth rates of capital services, 1970-2000, \% p.a., by method

$\begin{array}{llrrr}\text { Number } & \text { Name } & \text { Ex post } & (p . f .) & (A R) \\ 1 & \text { Agriculture } & 0.99 & 1.08 & 1.04 \\ 2 & \text { Oil \& gas } & 11.17 & 11.39 & 11.25 \\ 3 & \text { Coal \& other mining } & -1.40 & -0.96 & -1.05 \\ 4 & \text { Manufactured fuel } & -0.89 & -0.75 & -0.86 \\ 5 & \text { Chemicals \& pharmaceuticals } & 1.46 & 1.42 & 1.38 \\ 6 & \text { Non-metallic mineral products } & 3.27 & 3.66 & 3.49 \\ 7 & \text { Basic metals \& metal goods } & 0.13 & -0.01 & -0.04 \\ 8 & \text { Mechanical engineering } & 0.88 & 1.02 & 0.97 \\ 9 & \text { Electrical equipment \& electronics } & 4.05 & 4.36 & 4.30 \\ 10 & \text { Vehicles } & 2.65 & 2.22 & 2.17 \\ 11 & \text { Food, drink \& tobacco } & 2.06 & 2.13 & 2.11 \\ 12 & \text { Textiles, clothing \& leather } & -0.72 & -0.62 & -0.67 \\ 13 & \text { Paper, printing \& publishing } & 3.16 & 3.46 & 3.41 \\ 14 & \text { Other manufacturing } & 2.40 & 2.59 & 2.55 \\ 15 & \text { Electricity supply } & -0.56 & -0.51 & -0.51 \\ 16 & \text { Gas supply } & 1.06 & 1.06 & 1.15 \\ 17 & \text { Water supply } & 3.45 & 3.64 & 3.47 \\ 18 & \text { Construction } & 1.56 & 1.75 & 1.65 \\ 19 & \text { Wholesaling, vehicle repairs \& sales } & 5.13 & 5.72 & 5.66 \\ 20 & \text { Retailing } & 5.31 & 5.41 & 5.33 \\ 21 & \text { Hotels \& catering } & 5.44 & 5.27 & 5.22 \\ 22 & \text { Rail transport } & 0.05 & -0.28 & -0.25 \\ 23 & \text { Road transport } & 2.01 & 2.22 & 1.99 \\ 24 & \text { Water transport } & 1.50 & -0.16 & -0.21 \\ 25 & \text { Air transport } & 4.04 & 4.01 & 4.03 \\ 26 & \text { Other transport services } & 4.87 & 4.66 & 4.66 \\ 27 & \text { Communications } & 6.09 & 6.08 & 5.73 \\ 28 & \text { Finance } & 7.83 & 8.93 & 8.62 \\ 29 & \text { Business services } & 8.47 & 9.94 & 9.88 \\ 33 & \text { Waste treatment } & 5.11 & 4.66 & 4.46 \\ 34 & \text { Miscellaneous services } & 5.68 & 6.16 & 6.11 \\ & & & & \\ & \text { Cross-industry mean (unweighted) } & 3.10 & 3.21 & 3.13 \\ & & & & \end{array}$

Source Bank of England Industry Dataset.

Note 31 industries in the market sector. The two ex ante methods impose a common real rate of return of $8.66 \%$ p.a. in each year and every industry. p.f.: perfect foresight. 
Table 5

Growth rates and contributions of capital in the market sector, 1970-2000, \% p.a.:

$\begin{array}{lcc} & \text { Mean } & \text { S.D. } \\ \text { Growth rates } & & \\ \text { Ex post } & 4.52 & 1.44 \\ \text { Ex ante, perfect foresight } & 3.94 & 1.44 \\ \text { Ex ante, AR } & 3.81 & 1.41 \\ \text { Hybrid } & 4.84 & 1.60 \\ & & \\ \text { Contributions } & & \\ \text { Ex post } & 1.20 & 0.43 \\ \text { Ex ante, perfect foresight } & 1.05 & 0.36 \\ \text { Ex ante, AR } & 1.00 & 0.37 \\ \text { Hybrid } & 1.29 & 0.47\end{array}$

Source Bank of England Industry Dataset. 
Figure 1

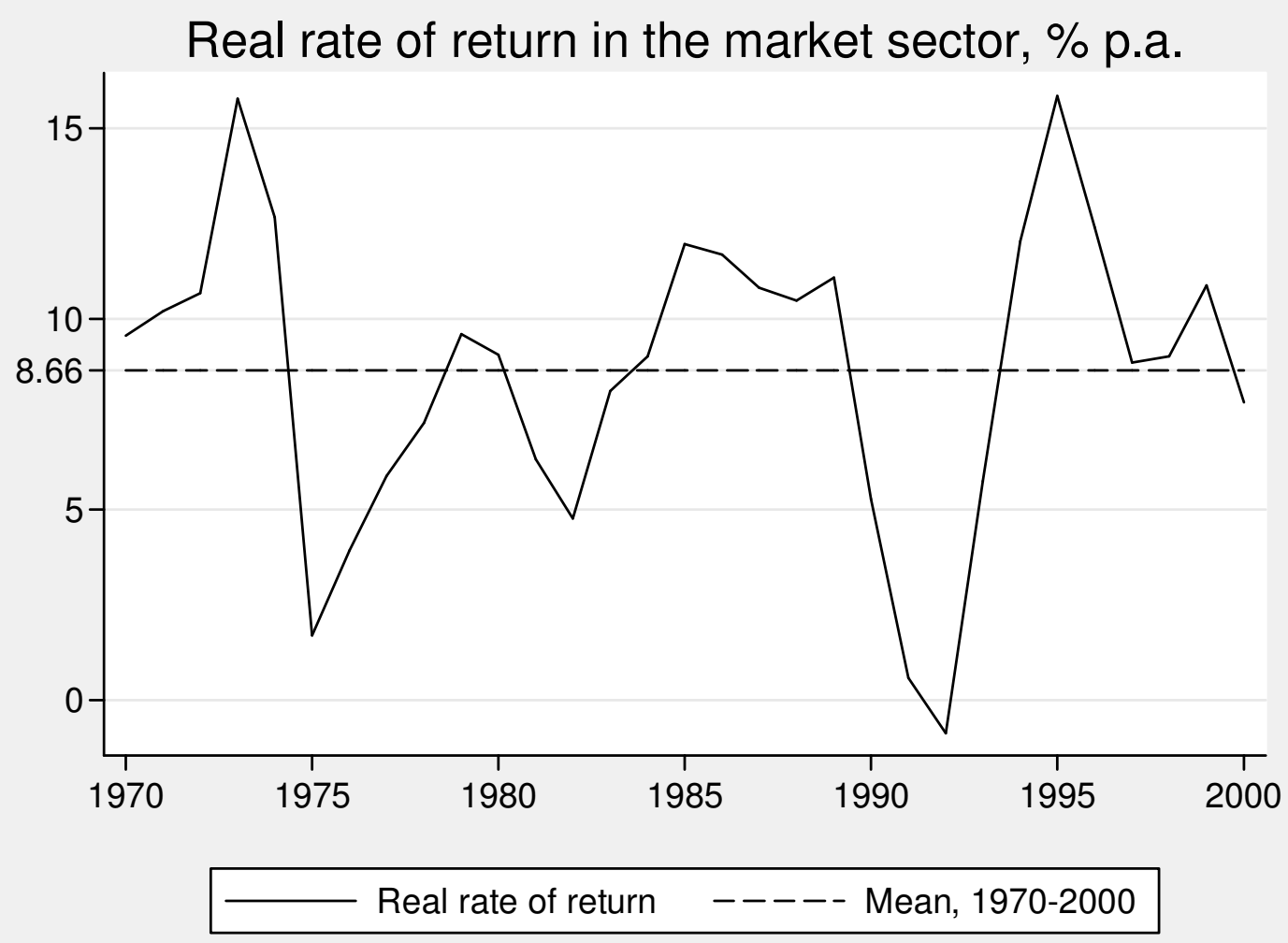


Figure 2

Capital services in the market sector, $1970=1.0$ log scale

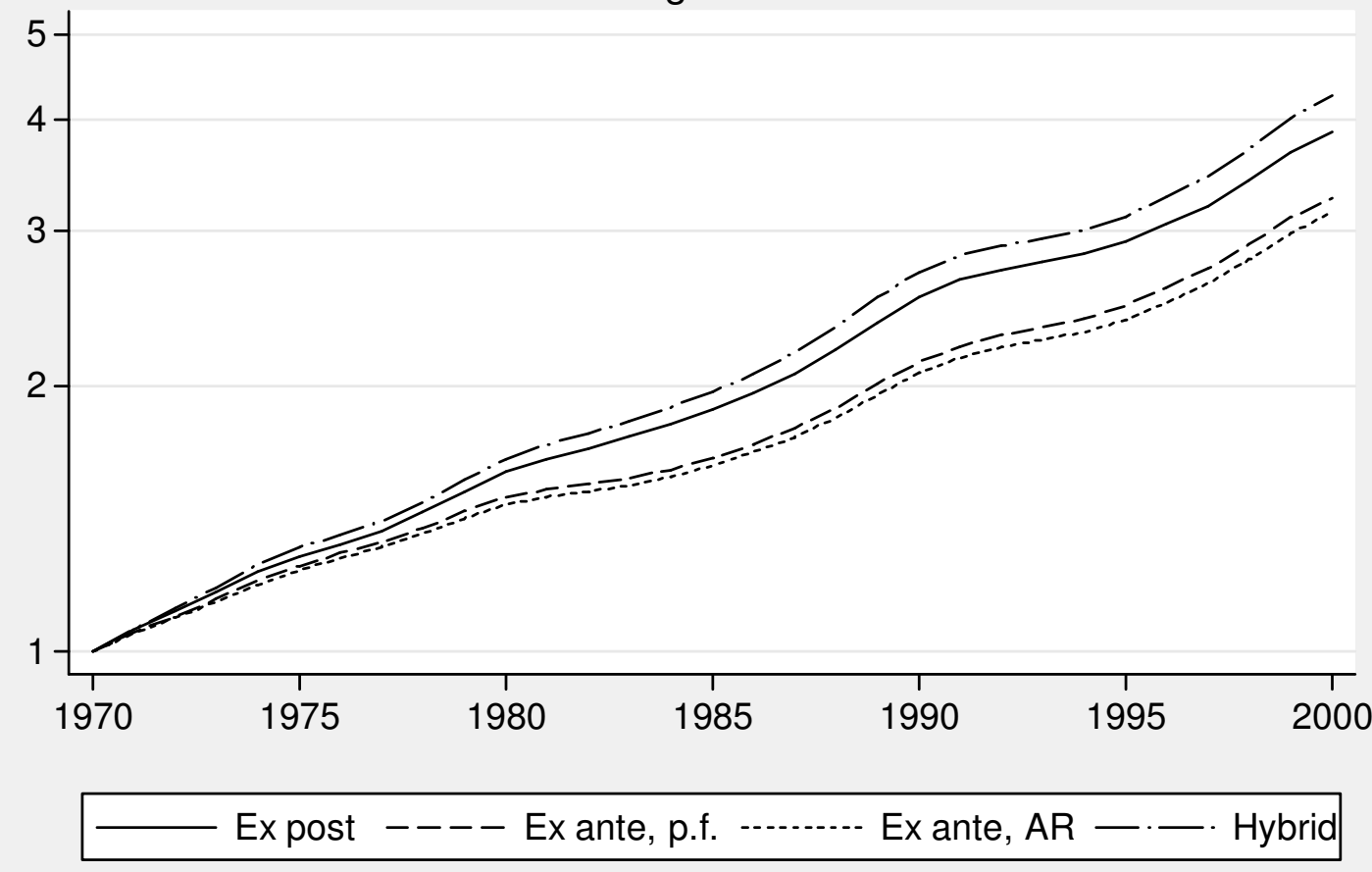


Figure 3

Growth rate of capital services in the market sector, \% p.a.

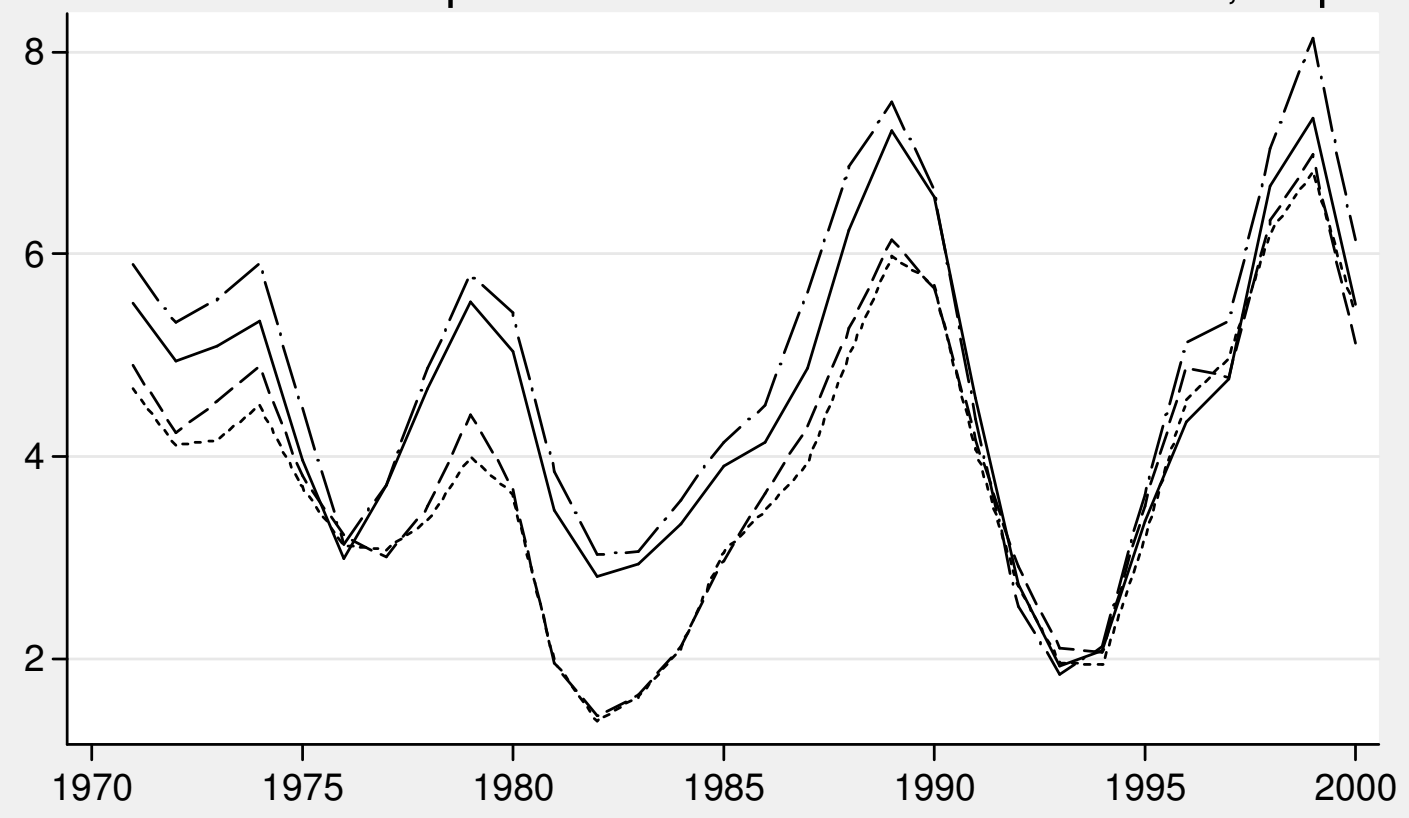

- Expost ---- Ex ante, p.f. -......... Ex ante, AR - - Hybrid 
Figure 4

Contribution of capital services in the market sector, \% p.a.

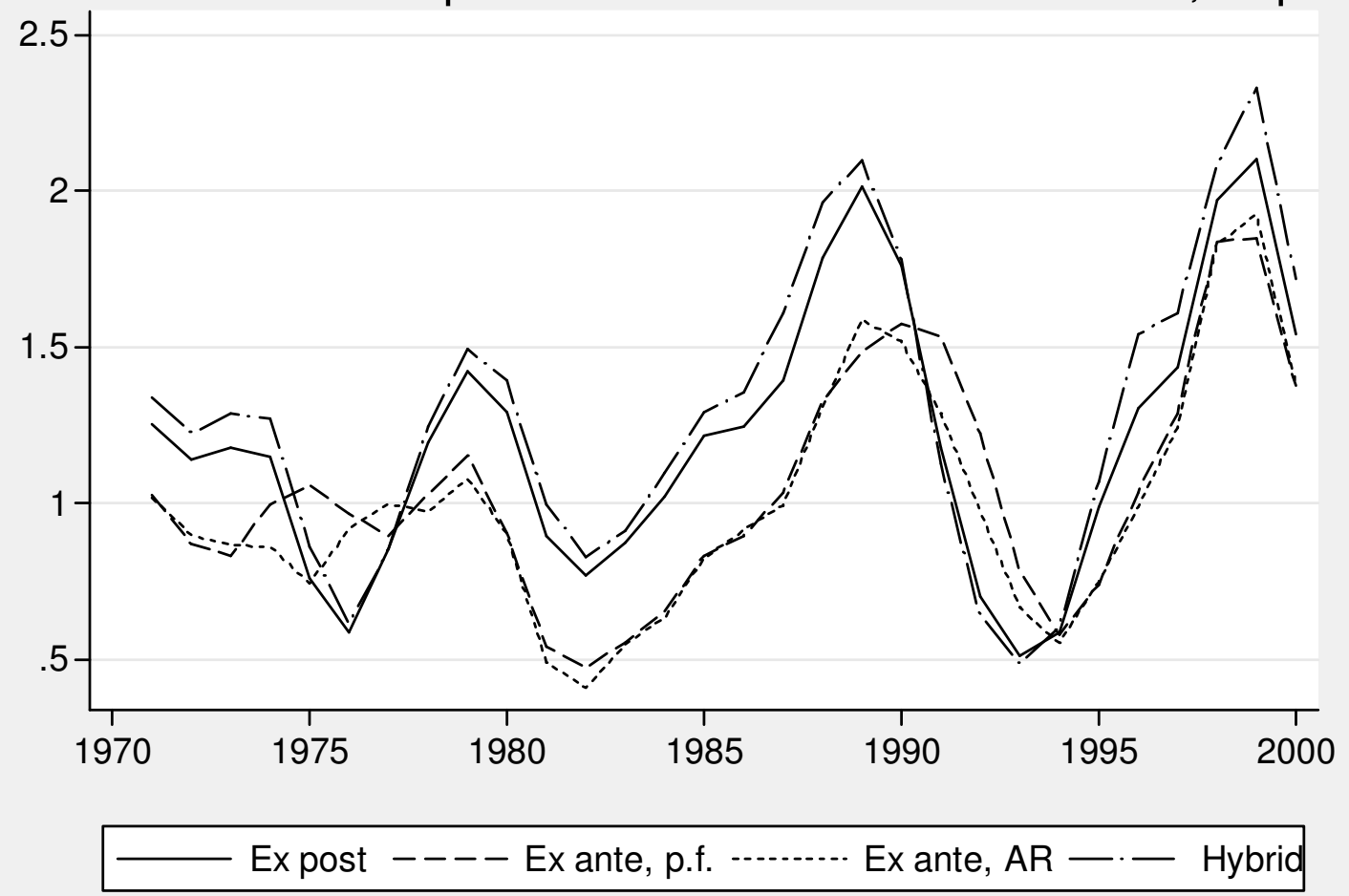


Figure 5

Growth of capital services versus real rate of return 29 industries, 1970-2000

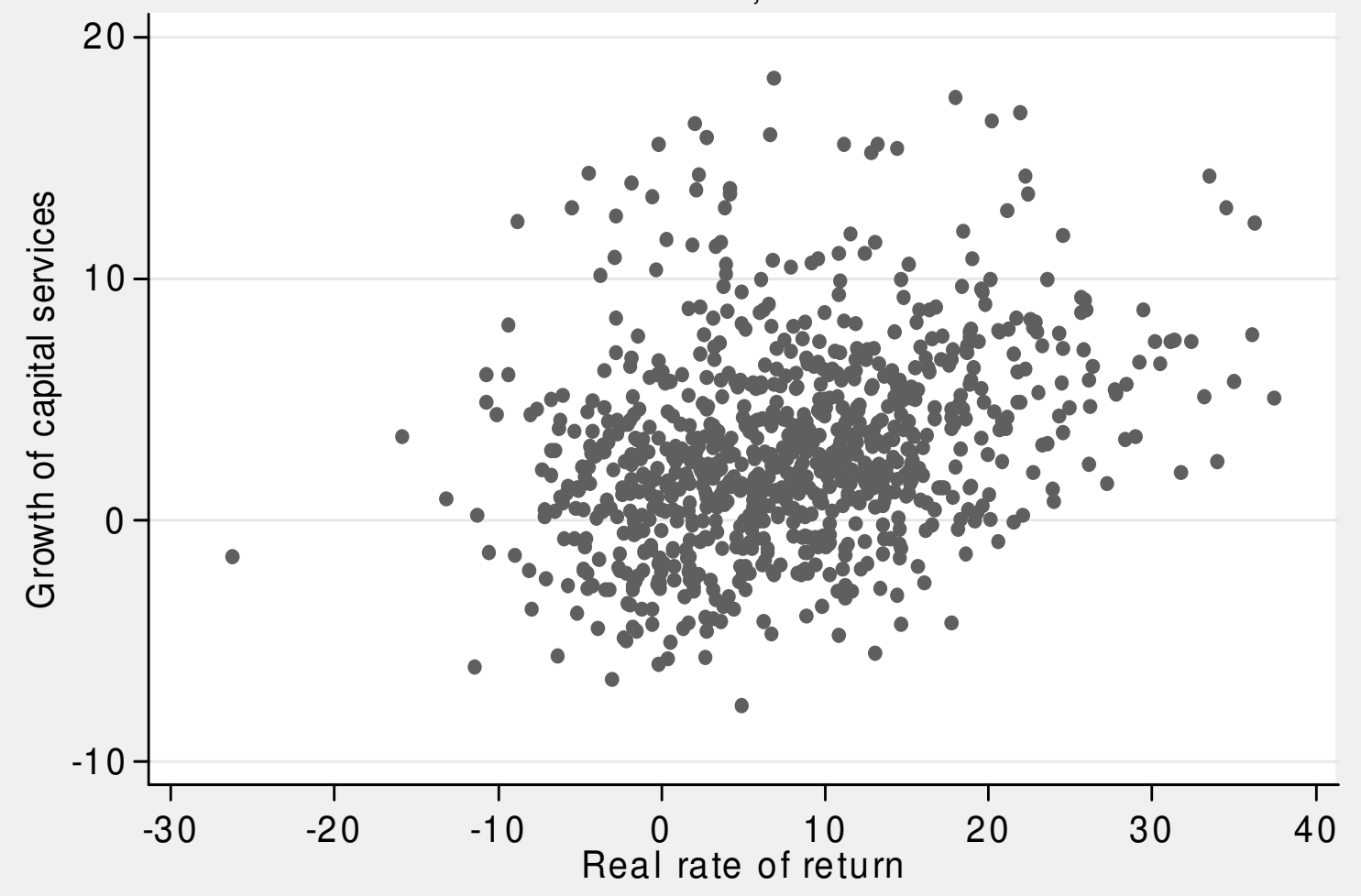

Note 870 annual observations. Industries 2 and 18 have been excluded as outliers.

Correlation coefficient is 0.31 . 


\section{Annex A Proofs of propositions in the text}

\section{A.1 Proof that the ex post rate of return varies across assets unless expectations are realised}

We prove the proposition stated in the text:

PROPOSITION. In the model set out above, and in the absence of a numerical fluke (to be defined below), the ex post rate of return will be the same for all assets if and only if all expectations (for asset prices, output price, the wage and output) are satisfied, in which case

the ex post and ex ante rates of return are equal. We prove the necessity part of the proposition since sufficiency is trivial.

Proof We start by assuming that asset price expectations are satisfied $\left(\pi_{i t}^{e}=\pi_{i t}, i=1, \ldots, m\right.$.), but not necessarily other expectations (we discuss relaxing this below). Assume that there is a common ex post rate of return which is a multiple $h$ of the ex ante rate of return:

$$
r_{i t}=h r_{t}^{*}, \quad h>0, h \neq 1, i=1, \ldots, m .
$$

Using (13),

$$
\frac{q_{i t}^{e}}{q_{i t}}=\frac{q_{j t}^{e}}{q_{j t}}, \quad i, j=1, \ldots, m
$$

for any two assets $i$ and $j$. Then setting $\left(\pi_{i t}^{e}=\pi_{i t}, i=1, \ldots, m\right.$.), applying the user cost formulas (1) and (9) in the previous equation, and re-arranging, we have

$$
h\left(x_{i t}-x_{j t}\right)=\left(x_{i t}-x_{j t}\right) \quad \text { where } x_{i t} \equiv \delta_{i}\left(1+\pi_{i t}\right)-\pi_{i t} .
$$

There are now two cases to consider.

(a) $x_{i t} \neq x_{j t}$, some $i, j$. Here the only solution for $h$ is $h=1$, contrary to the assumption. 
(b) $x_{i t}=x_{j t}, i, j=1, \ldots, m$. Here there are an infinity of solutions for $h$. But note that this equality must hold for all $i$ and $j$, otherwise case (a) would apply. This would mean that all assets are essentially identical in economic terms (at least in the current period). If case (b) is ruled out as an uninteresting special case, the only economically relevant solution is case (a) where $h=1$. We now show this implies either that expectations about output and its price (as well as about asset prices) are satisfied or the presence of a numerical fluke.

If $h=1$, expected nominal profits are

$$
p_{Y t}^{e} S_{t}^{e}=T_{i t}\left(r_{t}^{*}+x_{i t}\right) p_{i, t-1} K_{i t}
$$

and actual nominal profits are

$$
p_{Y t} S_{t}=T_{i t}\left(r_{t}^{*}+x_{i t}\right) p_{i, t-1} K_{i t} \text {. }
$$

So expected and actual nominal profits are equal which implies:

$$
\begin{aligned}
\frac{p_{Y t}}{p_{Y t}^{e}} & =\frac{S_{t}^{e}}{S_{t}} \\
& =\frac{E_{t-1}\left[B_{t}^{(\sigma-1) / \sigma} Y_{t}^{1 / \sigma}\right]}{B_{t}^{(\sigma-1) / \sigma} Y_{t}^{1 / \sigma}}
\end{aligned}
$$

from (16). This implies that if actual prices are higher than expected, then output will be lower than expected, in the same proportion. But the supply curve is positively sloped. So the relationship we have just found between prices and output could only occur if there were offsetting changes in the other variables shifting the supply curve (TFP and wages). So either expectations about output and its price are satisfied:

$$
\frac{p_{Y t}}{p_{Y t}^{e}}=\frac{E_{t-1}\left[B_{t}^{(\sigma-1) / \sigma} Y_{t}^{1 / \sigma}\right]}{B_{t}^{(\sigma-1) / \sigma} Y_{t}^{1 / \sigma}}=1
$$


or TFP and wages shift in such a way that, even if expectations are not satisfied, equation (A.1) remains true. But since TFP and wages are exogenous in our model, this would amount to a numerical fluke, as asserted in the Proposition.

Comment Of course, if asset price expectations are not satisfied, it would always be possible to find some set of realised prices that are consistent with a common ex post rate of return. But for these prices actually to occur would also be a numerical fluke. Hence we can conclude more generally that in the absence of such a fluke, ex post rates of return will normally differ between assets.

\section{A.2 The translog case}

The translog production function with $m$ inputs $X_{i}$ and constant returns to scale can be written in log form as:

$$
\begin{gathered}
\ln Y=\alpha_{0}+\sum_{i=1}^{m} \alpha_{i} \ln X_{i}+(1 / 2) \sum_{i=1}^{m} \sum_{j=1}^{m} \beta_{i j} \ln X_{i} \ln X_{j}+\alpha_{t} t+\sum_{i=1}^{m} \beta_{i t} \ln X_{i} t+\beta_{t t} t^{2}, \\
\sum_{i=1}^{m} \alpha_{i}=1, \sum_{j=1}^{m} \beta_{i j}=0, \quad \beta_{i j}=\beta_{j i}
\end{gathered}
$$

The elasticity of output $(Y)$ with respect to the $i$ th input $\left(X_{i}\right), \varepsilon_{i}$, is:

$$
\varepsilon_{i}=\alpha_{i}+\sum_{j=1}^{m} \beta_{i j} \ln X_{j}+\beta_{i t} t, i=1, \ldots, m
$$

These elasticities, if we could measure them, are what we would like to use in a growth accounting analysis. Now suppose that only the $m$ th input can be varied in the short run, inputs 1 to $m-1$ being fixed (this can be easily generalised to any number of freely variable inputs). Then the expected elasticity of output with respect to the $i$ th fixed input, after the levels of the fixed inputs have been chosen $\left(X_{j}=\bar{X}_{j}, j=1, \ldots, m-1\right)$, is:

$$
E\left(\varepsilon_{i}\right)=\alpha_{i}+\sum_{j=1}^{m-1} \beta_{i j} \ln \bar{X}_{j}+\beta_{i m} E\left[\ln X_{m}\right]+\beta_{i t} t
$$


We can estimate the expected elasticity from estimates of expected user costs. The actual elasticity is

$$
\varepsilon_{i}=\alpha_{i}+\sum_{j=1}^{m-1} \beta_{i j} \ln \bar{X}_{j}+\beta_{i m} \ln X_{m}+\beta_{i t} t
$$

The marginal product of the $i$ th input is $\varepsilon_{i} Y / X_{i}$. The ratio of the expected to the actual marginal product of the $i$ th fixed input is $E\left(\varepsilon_{i} Y\right) / \varepsilon_{i} Y$. Now if $\beta_{i m}=0$, all $i$, then from the last two equations $E\left(\varepsilon_{i}\right)=\varepsilon_{i}$ and hence $E\left(\varepsilon_{i} Y\right) / \varepsilon_{i} Y=E(Y) / Y$. That is, the ratio of the expected to the actual marginal product is the same for all fixed inputs just as in the CES case. If the $\beta_{i m}$ are sufficiently small, even if not zero, then this result will still hold approximately.

In practice the $\beta_{i j}$ coefficients do appear to be quite small and not to vary very much between industries. For example, Jorgenson et al (1987, Table 7.3 and Appendices B-D) report estimates of the coefficients of a translog production function with three inputs (capital $(K)$, labour $(L)$ and intermediate $(X))$ fitted to $21 \mathrm{U} . \mathrm{S}$. manufacturing industries. Interpreting this as a system with one quasi-fixed input (capital) and two freely variable ones (labour and intermediate), we are then interested in the values of the $\beta_{K L}$ and $\beta_{K X}$ coefficients. The $\beta_{K L}$ coefficient averaged 0.05 with standard deviation of 0.08 ; the $\beta_{K X}$ coefficient averaged 0.002 with standard deviation of 0.007 . This suggests that the approximation implied by use of a CES production function is not too bad in this context.

\section{Annex B Calibrating the three-input CES production function}

The three-input CES production function is:

$$
Y_{t}=B_{t}\left[a_{1} K_{1 t}^{(\sigma-1) / \sigma}+a_{2} K_{2 t}^{(\sigma-1) / \sigma}+a_{3} L_{t}^{(\sigma-1) / \sigma}\right]^{\sigma /(\sigma-1)} .
$$

Cost minimisation requires equating marginal products with real input prices: 


$$
\begin{aligned}
& \frac{\partial Y_{t}}{\partial K_{1 t}}=a_{1} B_{t}^{(\sigma-1) / \sigma}\left(\frac{Y_{t}}{K_{1 t}}\right)^{1 / \sigma}=q_{1 t} \\
& \frac{\partial Y_{t}}{\partial K_{2 t}}=a_{2} B_{t}^{(\sigma-1) / \sigma}\left(\frac{Y_{t}}{K_{2 t}}\right)^{1 / \sigma}=q_{2 t} \\
& \frac{\partial Y_{t}}{\partial L_{t}}=a_{3} B_{t}^{(\sigma-1) / \sigma}\left(\frac{Y_{t}}{L_{t}}\right)^{1 / \sigma}=w_{t}
\end{aligned}
$$

where $w$ is the real wage. Define the productivity ratios: $y_{1 t} \equiv Y_{t} / K_{1 t}, y_{2 t} \equiv Y_{t} / K_{2 t}, y_{3 t} \equiv Y_{t} / L_{t}$. Solving for these productivity ratios:

$$
\begin{aligned}
& y_{1 t}=B_{t}^{1-\sigma}\left(q_{1 t} / a_{1}\right)^{\sigma} \\
& y_{2 t}=B_{t}^{1-\sigma}\left(q_{2 t} / a_{2}\right)^{\sigma} \\
& y_{3 t}=B_{t}^{1-\sigma}\left(w_{t} / a_{3}\right)^{\sigma} .
\end{aligned}
$$

Applying Euler's theorem,

$$
Y_{t}=q_{1 t} K_{1 t}+q_{2 t} K_{2 t}+w_{t} L_{t}
$$

hence

$$
y_{1 t}=q_{1 t}+q_{2 t}\left(y_{1 t} / y_{2 t}\right)+w_{t}\left(y_{1 t} / y_{3 t}\right) \text {. }
$$

(B.1) and (B.2) constitute four equations which we can use to solve for four unknowns. We take the two user costs of capital as known and the unknowns to be the three productivity ratios and the third real input price, the real wage. We then solve for the real wage in terms of the user costs and the production function parameters:

$$
w_{t}=B_{t} a_{3}^{-\sigma}\left[1-\left(q_{1 t} / y_{1 t}\right)-\left(q_{2 t} / y_{2 t}\right)\right]^{1 /(1-\sigma)}
$$

Note that $y_{1 t}$ and $y_{2 t}$ can be found from (B.1). 
Next, the parameters of the production function (the $a_{i}$ ) can be pinned down by imposing two empirical requirements. First, the income share of capital (gross operating surplus as a proportion of the value of output), denoted by $v_{K}$, should be consistent with empirical evidence, eg $40 \%$. Second, the proportion of profits due to ICT, denoted by $v_{C}$, should take a plausible value, eg $15 \%$. Given these requirements, we can determine $a_{1}, a_{2}, a_{3}$ as follows. The first requirement can be written as:

$$
\left(q_{1 t} / y_{1 t}\right)+\left(q_{2 t} / y_{2 t}\right)=v_{K}
$$

which from (B.1) yields

$$
B_{t}^{\sigma-1}\left[q_{1 t}^{1-\sigma} a_{1}^{\sigma}+q_{2 t}^{1-\sigma} a_{2}^{\sigma}\right]=v_{K}
$$

And the second requirement can be written as:

$$
\left(q_{2 t} / y_{2 t}\right) /\left(q_{1 t} / y_{1 t}\right)=v_{C} /\left(1-v_{C}\right)
$$

which yields

$$
q_{2 t}^{1-\sigma} a_{2}^{\sigma} / q_{1 t}^{1-\sigma} a_{1}^{\sigma}=v_{C} /\left(1-v_{C}\right)
$$

and solving for $a_{2}$,

$$
a_{2}=\left[\left(q_{1 t} / q_{2 t}\right)^{(1-\sigma)}\left(v_{C} /\left(1-v_{C}\right)\right)\right]^{1 / \sigma} a_{1}=h a_{1} \text { say }
$$

We can normalise the $a_{i}$ to sum to one:

$$
a_{1}+a_{2}+a_{3}=1
$$

and we can also normalise the level of TFP to equal one: $B_{t}=1$ 
Now substituting (B.5) into (B.4), and solving for $a_{1}$, we obtain

$$
a_{1}=\left[v_{K} /\left(q_{1 t}^{1-\sigma}+q_{2 t}^{1-\sigma} h^{\sigma}\right)\right]^{1 / \sigma}
$$

These relationships, equations (B.5), (B.6) and (B.7), suffice to determine $a_{1}, a_{2}, a_{3}$ as functions of the elasticity of substitution, the two empirically observable shares $\left(v_{K}\right.$ and $\left.v_{C}\right)$, and the two user costs of capital. (Note that these results apply too to the Cobb-Douglas case $(\sigma=1)$ when the user costs drop out). 


\section{References}

Berndt, E.R. (1990), ‘Comments on Hulten'. In Ernst R Berndt and Jack Triplett (eds), Fifty Years of Economic Measurement, Chicago: Chicago University Press for NBER.

Berndt, E.R. and Fuss, M.A. (1986), 'Productivity measurement with adjustments for variations in capacity utilisation and other forms of temporary equilibrium', Journal of Econometrics, vol. 33, pages 7-29.

Christensen, L. and Jorgenson, D.W. (1969), 'The measurement of U.S. real capital input, 1929-1967', Review of Income and Wealth, series 15, no. 4 (December), pages 293-320.

Diewert, W.E. (1980), 'Aggregation problems in the measurement of capital', in Usher, D (ed), The measurement of capital, Studies in Income and Wealth No. 45, pages 433-528, Chicago: The University of Chicago Press.

Diewert, W.E. (2001), 'Measuring the price and quantity of capital services under alternative assumptions', Department of Economics, University of British Columbia, Discussion Paper no. 01-24.

Harper, D.J., Berndt, E.R., Wood, D.O. (1989), 'Rates of return and capital aggregation using alternative rental prices', in D.W. Jorgenson and R. Landau (eds), Technology and Capital Formation, Cambridge, MA: The MIT Press.

Jorgenson, D.W. (1989), 'Capital as a factor of production', in Jorgenson, D. W., and Landau, R. (eds), Technology and capital formation, Cambridge, MA: The MIT Press.

Jorgenson, D.W., Gollop, F.M. and Fraumeni, B.M. (1987), Productivity and U.S. economic growth, Cambridge, MA.: Harvard University Press.

Jorgenson, D.W., and Griliches, Z. (1967), 'The explanation of productivity change', Review of Economic Studies, vol. 34, pages 249-83; reprinted in D W Jorgenson, Productivity: volume 1: postwar U.S. economic growth, Cambridge, MA: The MIT Press.

OECD (2001a), OECD Productivity Manual: A Guide to the Measurement of Industry-Level and Aggregate Productivity Growth, Paris: OECD.

OECD (2001b), Measuring capital: a manual on the measurement of capital stocks, consumption of fixed capital and capital services, Paris: OECD.

O'Mahony, M. and van Ark, B. (2003), EU Productivity and Competitiveness: An Industry Perspective, Luxembourg: European Commission. 
Oulton, N. and Srinivasan, S. (2003), 'Capital stocks, capital services, and depreciation: an integrated framework', Bank of England Working Paper no. 192. Available at http://www.bankofengland.co.uk/workingpapers/wp192.pdf.

Oulton, N. and Srinivasan, S. (2005), 'Productivity growth in UK industries, 1970-2000: structural change and the role of ICT', Bank of England Working Paper no. 259. Available at http://www.bankofengland.co.uk/workingpapers/wp259.pdf.

Schreyer, P. (2004), 'Measuring multi-factor productivity when rates of return are exogenous', OECD, mimeo.

Schreyer, P., Bignon, P.-E., and Dupont, J. (2003), 'OECD capital services estimates: methodology and a first set of results', OECD Statistics Working Paper 2003/6. Available at http://www.olis.oecd.org/olis/2003doc.nsf/LinkTo/std-doc(2003)6. 